\title{
KREATIVITAS UDJO NGALAGENA : STUDI KEBERHASILAN PENGEMBANGAN KREATIVITAS DI SAUNG ANGKLUNG UDJO (SAU)
}

\author{
Budiman Mahmud M \\ Laboratorium Pariwisata, Program Vokasi Universitas Indonesia, b.mahmud@ui.ac.id
}

\begin{abstract}
Diterima : 12 Desember 2014
Layak Terbit : 3 Januari 2015

Abstrak

Arikel ini merupakan hasil penelitian kualitatif yang membahas tentang kreativitas, khususnya tentang kreativitas Udjo Ngalagena baik dari sisi pribadi, pendorong, proses dan produk kreatif. Hasil penelitian menunjukkan bahwa berbagai potensi yang dimiliki Udjo dan dukungan dari lingkungan keluarga, masyarakat dan sekolah (pendidikan) membuat Udjo menjadi pribadi kreatif. Pribadi dan dorongan kreatif memberikan kekuatan bagi Udjo Ngalagena untuk terus melakukan dan mengembangkan kreativitasnya ditengah berbagai tantangan dan kondisi zaman. Udjo Ngalagena berhasil mengemas tradisi angklung menjadi produk kreatif dalam aktivitas pendidikan, produksi dan pertunjukkan yang berjalan secara rutin dan formal di Saung Angklung Udjo (SAU) dengan mengacu pada nilai-nilai tradisi Sunda. Keberadaan dan perkembangan SAU di Bandung, Jawa Barat selama hampir 50 tahun membuktikan bahwa Udjo Ngalagena berhasil melakukan regenerasi dan melahirkan generasi-generasi kreatif dan berhasil memperkokoh eksistensi budaya local
\end{abstract}

Kata Kunci: Kreativitas, Udjo Ngalagena, Saung Angklung Udjo.

\begin{abstract}
This article is the result of qualitative research which focused on creativity, especially creativity Udjo Ngalagena in terms of personal, press, processes and products. The results showed that the various potentials and support from the family, community and school (education) makes Udjo being personally creative. Personal creative and press factor gives strength to Udjo Ngalagena to continue and develop their creativity amid the challenges and conditions of the times. Udjo Ngalagena succeeded in making angklung tradition into creative products in educational activities, production and performances regularly and formally at Saung Angklung Udjo (SAU) with reference to the traditional values of Sunda. The existence and development of the SAU in Bandung, West Java for almost a 50 years proves that Udjo Ngalagena succeeded in creating generations of creative and successfully strengthen the local cultural existence
\end{abstract}

Keywords:. Creativity, Udjo Ngalagena, Saung Angklung Udjo

\section{PENDAHULUAN}

\section{Latar Belakang}

Sejarah lahirnya peradaban sebagaimana dikemukakan oleh Toynbee ditentukan oleh minoritas kreatif dan kondisi lingkungan. Hal yang sama juga dikemukakan oleh Sorokin yang menjelaskan bahwa lingkungan terus menerus menantang masyarakat dan melalui minoritas kreatif ditentukan cara menanggapi tantangan tersebut (Sztompka, 2011). Studi mengenai kekuatan minoritas kreatif masih sangat relevan untuk menjawab berbagai tantangan dan permasalahan di era globalilasi budaya saat ini. Ife (2013) menjelaskan bahwa globalisasi budaya berjalan mengikuti pola yang sama dengan globalisasi ekonomi dan kondisi ini memberikan dampak terhadap eksistensi budaya lokal. Atas dasar inilah maka penulis melihat salah satu tantangan di era globalisasi budaya adalah keberadaan 
individu kreatif dan eksistensi budaya lokal. Kajian ini mencoba untuk mengkaji lebih dalam tentang kekuatan tokoh kreatif dibidang kebudayaan (seni tradisi) dengan mengangkat suatu studi kasus tentang kreativitas Udjo Ngalagena (1929-2001) dalam mengembangkan Saung Angklung Udjo. Kemampuan dan keberhasilan Udjo Ngalagena menjadi pribadi kreatif yang menghasilkan berbagai produk kreatif ditengah berbagai kondisi zaman dan karyanya mendunia serta bertahan lebih dari 50 tahun dapat menjadi inspirasi bagi masyarakat untuk melahirkan dan membina generasi kreatif yang siap menghadapi berbagai tantangan zaman.

Kreativitas dapat diartikan sebagai suatu kemampuan umum untuk menciptakan suatu yang baru atau kemampuan untuk memberikan gagasan-gagasan baru yang dapat diterapkan dalam pemecahan masalah, atau sebagai kemampuan untuk melihat hubungan-hubungan baru antara unsur-unsur yang sudah ada sebelumnya (Munandar, 2012 : 25). Menurut Munandar, sesuatu yang diciptakan itu tidak perlu baru sekali, tetapi merupakan gabungan atau kombinasi dari halhal yang sudah ada sebelumnya (Munandar, 1988; 1990; 1999; 2012). Semiawan (2009: 44) mendefinisikan kreativitas sebagai modifikasi sesuatu yang sudah ada menjadi konsep baru. Berbeda dengan definisi diatas yang berakar pada kajian psikologi, kreativitas juga telah lama dilakukan dari kajian ilmu sosiologi dan antropologi. Selo Soemardjan (1983:93) menegaskan bahwa timbul dan tumbuhnya kreativitas dan selanjutnya berkembang menjadi suatu kreasi yang diciptakan oleh seseorang individu tidak dapat luput dari pengaruh kebudayaan serta pengaruh masyarakat tempat individu itu hidup dan bekerja. Hal ini diperkuat oleh Ember (Ember \& Ember, 1996:125) yang menjelaskan bahwa tokoh yang menciptakan suatu kreasi baru pada prosesnya dipengaruhi oleh kondisi sosial budaya masyarakatnya, melalui hubungan antara individu dan kebudayaannya, kreativitas dimungkinkan berkembang dengan lebih baik.

Udjo Ngalagena sebagai tokoh yang berhasil di bidang seni tradisi angklung memiliki karya monumental yaitu Saung Angklung Udjo di Bandung, Jawa Barat dan mempunyai pengaruh yang sangat besar di masyarakat (Syafii, 2009; Milyartini, 2012). Sosok Udjo Ngalagena sebagai minoritas kreatif memegang peranan sangat penting dibalik keberhasilan SAU selama setengah abad. Kajian ini mencoba untuk mengangkat keberhasilan Udjo Ngalagena sebagai tokoh kreatif yang berhasil mempertahankan eksistensi budaya lokal dan mengembangkannya selama lebih dari 50 tahun

Udjo Ngalagena berhasil menciptakan kreasi baru yang memungkinkan masyarakat terlibat dalam mengekspresikan dirinya dan kreativitasnya dalam kegiatan seni tradisi. Secara teoritik, perlu dipertanyakan dan diperdalam, bagaimana teori pembentukan pribadi kreatif dapat menjelaskan kreativitas Udjo Ngalagena dan berbagai dorongan serta pengaruh lingkungan sehingga ia mampu kreatif dalam berbagai kondisi zaman. 
Kreativitas tidak hanya berhenti pada pribadi kreatif, tetapi bagaimana pribadi tersebut dapat melakukan proses kreatif sehingga menghasilkan produk kreatif yang memiliki nilai tambah bukan hanya bagi penciptanya tetapi juga bagi masyarakat. Atas permasalahan ini maka perlu digali dan dikaji lebih dalam tentang kemampuan Udjo Ngalagena dalam melakukan proses kreatif dan menghasilkan produk kreatif.

Permasalahan lainnya terkait dengan eksistensi budaya lokal yaitu daya tahan suatu aktivitas dan produk kreatif seni tradisi. Hal ini penting karena secara fakta cukup banyak kreativitas dibidang seni tradisi yang tidak bertahan lama, termarginalkan oleh berbagai budaya popular dan budaya asing, bahkan tidak sedikit seni tradisi yang ditinggalkan oleh masyarakatnya, namun SAU menunjukkan fakta yang sebaliknya, Udjo Ngalagena berhasil menciptakan tradisi baru terkait angklung baik dari sisi produksi angklung, pendidikan angklung maupun pertunjukkan angklung dengan tetap mengacu pada tradisi sunda masa lalu. Pertanyaan utama yang hendak dijawab dalam kajian ini adalah bagaimana Udjo Ngalagena menjadi pribadi kreatif yang produk kreatifnya dapat bertahan selama lebih dari 50 tahun?

\section{METODE}

Pendekatan yang digunakan adalah pendekatan kualitatif. Kajian ini merupakan hasil dari penelitian kualitatif yang berusaha untuk mengemukakan pengetahuan mendasar mengenai suatu fenomena sosial (kasus) yaitu tentang kreativitas Udjo Ngalagena. Kajian ini bersifat eksplanasi yang bertujuan untuk menjelaskan alasan terjadinya peristiwa dan untuk membentuk, memperdalam, mengembangkan teori (Neuman, 2013:45). Kajian ini menekankan pada studi kasus dalam upaya memahami kreativitas secara utuh, lebih mendalam dan lebih detail, dalam hal ini adalah studi kasus kreativitas Udjo Ngalagena di SAU yang berlokasi di Jalan Padasuka No 118, Bandung, Jawa Barat. Data primer diperoleh peneliti melalui observasi dan wawancara terhadap informan seperti keluarga, pengrajin, murid, pemain, pelatih, tokoh masyarakat dan berbagai informan lainnya. Data sekunder dalam penelitian ini diperoleh melalui kegiatan studi pustaka, berupa penelusuran dokumen yang memuat fakta-fakta, artikel atau referensi, serta bahanbahan lain yang menunjang terkait dengan kreativitas, aktivitas Udjo Ngalagena dan aktivitas di Saung Angklung Udjo

\section{HASIL DAN PEMBAHASAN}

\section{Kreativitas Sebuah Tinjauan Singkat}

Kajian-kajian para ahli mengenai kreativitas secara umum menjelaskan bahwa keberadaan minoritas kreatif sangat penting dalam kehidupan manusia untuk menjawab berbagai tantangan zaman serta mengubah dan mengembangkan kebudayaan (Munandar, 1988; 2009; 2012; Semiawan, 2009; Sztompka, 2011; Soemardjan, 1983). Pada konteks globalisasi budaya yang ada saat ini, studi mengenai minoritas kreatif masih sangat 
relevan untuk menjawab berbagai tantangan dan permasalahan yang dihadapi masyarakat. Salah satu tantangan di era globalisasi budaya adalah eksistensi budaya lokal (Ife, 2013).

Berdasarkan berbagai kajian yang ada, kreativitas dapat terjadi pada bidang psikologi (Munandar, 1988; 1990; 1999; 2012 dan Semiawan, 2009), manajemen (Fontana, 2009; Anderson, 2014), sosial budaya (Bachtiar, 1983; Soemardjan, 1983; Ember, 1996; Fischer, 2009; 2012; 2014) dan berbagai bidang lainnya. Secara sosial budaya setiap zaman memberikan tantangannya masingmasing dan di era global saat ini, perkembangan globalisasi budaya menjadi tantangan yang harus dihadapi oleh manusia kreatif karena globalisasi budaya telah memberikan dampak yang besar bagi eksistensi kebudayaan masyarakat (Ife, 2013). Globalisasi budaya dan derasnya arus perubahan serta masuknya kebudayaan asing memberikan dampak terhadap eksistensi budaya masyarakat lokal (Ife, 2013:237). Pandangan Ife tersebut kiranya relevan dengan pengalaman dan berbagai kondisi nyata yang dirasakan di Indonesia terkait globalisasi budaya dan berbagai dampaknya. Beberapa kajian menunjukkan bahwa globalisasi yang melanda Indonesia saat ini memberikan dampak dan sudah ada gejala semakin ditinggalkannya seni tradisi, misalnya wayang orang, wayang potehi, seni kasidah, seni gambang (Jamil,2011), kesenian Reog (Supariadi, 2012), Ludruk (Taufik, 2008, Azali, 2012), di Jawa Barat sedikitnya terdapat 43 kesenian tradisional yang hampir punah (kompas.com, 2009), serta studi tentang kegagalan regenerasi kreativitas seniman tradisional (Yulianti, 2013). Berbagai permasalahan ini perlu menjadi perhatian serius bukan saja oleh seniman, tetapi juga oleh akademisi dan masyarakat luas sehingga dampak globalisasi budaya yang sudah ada ini tidak semakin memperparah keadaan.

Dari berbagai bidang keilmuan yang membahas tentang kreativitas ada satu pendekatan umum yang dapat digunakan oleh berbagai bidang kelimuan dalam menganalisa kreativitas sebagaimana dikemukakan oleh Rhodes (1961) yaitu pendekatan 4P yaitu person (pribadi), press (pendorong), process (proses), dan product (produk) (Munandar, 1999;2012). Menurut Munandar, dari keempat pendekatan tersebut hal yang paling menentukan dalam proses perwujudan kreativitas adalah aspek pribadi (person). Istilah kepribadian digunakan untuk menjelaskan karakteristik pribadi seseorang yang menyebabkan munculnya konsistensi perasaan, pemikiran, dan perilaku (Pervin, 2010). Teori yang akan digunakan oleh peneliti pada kajian ini adalah teori Carl Roger (1902-1987) yang tergolong dalam aliran teori humanistik. Teori Carl Roger bertitik tolak dari pandangan bahwa manusia menentukan nasibnya sendiri. Carl Rogers mengutarakan sebuah teori yang disebut dengan teori pribadi terpusat, dimana tiap individu ada dalam dunia pengalaman yang selalu berubah dan individu tersebut menjadi pusatnya. Teori Roger tentang aktualisasi diri menekankan pada konsistensi diri dan kongruensi antara diri dan pengalaman (Pervin, 2010). Aktualisasi diri mendorong 
manusia sampai kepada pengembangan yang optimal dan menghasilkan ciri unik manusia seperti kreativitas, inovasi, dan lain-lain. Aliran humanistik menyumbangkan arah yang positif dan optimis bagi pengembangan potensi manusia (Munandar, 1999; Pervin, 2010).

Berbagai studi terdahulu menunjukkan bahwa ada akademisi yang mengkaji dari semua sisi, seperti Munandar (1988; 1999; 2012) yang fokus pada kreativitas di bidang pendidikan, Palaniappan (2012) tentang kreativitas berbasis budaya. Studi yang menekankan pada dimensi pribadi atau tokoh kreatif antara lain Mushnikova (2014) tentang tokoh pelukis terkemuka di Rusia, Almasitoh (2013) tentang kepribadian kreatif, Kalyar (2011) tentang kreativitas dan kepemimpinan. Studi yang menekankan pada proses, seperti Cameron (2013) tentang kolaborasi seniman dan profesi kesehatan, Cirella (2012) tentang kreativitas kolektif, Fischer (2009; 2011; 2014) tentang kreativitas sosial. Studi yang menekankan pada produk seperti Simonton (1980) tentang komposisi musik, Amabile (1983) tentang karya seni lukis, Glăveanu (2012) tentang kreativitas berupa kerajinan tradisional, Lande (2007) tentang inovasi musik tradisi Jepang.

\section{Kreativitas Udjo Ngalagena}

Berbagai aktivitas dan produk kreatif Udjo Ngalagena merupakan salah satu wujud aktualisasi dirinya. Hal ini mengacu pada teori Rogers yang mendasarkan pada suatu "daya hidup" yang disebut dengan kecenderungan aktualisasi (Munandar, 1998; Pervin, 2010).
Kecenderungan aktualisasi tersebut diartikan sebagai motivasi yang menyatu dalam setiap diri makhluk hidup dan bertujuan mengembangkan seluruh potensinya semaksimal mungkin. Jadi, makhluk hidup bukan hanya bertujuan bertahan hidup saja, tetapi ingin memperoleh apa yang terbaik bagi keberadaannya. Aktualisasi diri di bidang seni tradisi mendorong Udjo mampu mengembangkan berbagai potensi yang dimilikinya sehingga ia menjadi pribadi kreatif yang menghasilkan berbagai produk kreatif. Perjalanan hidup dan proes kreatif yang Udjo lalui menjadikannya memiliki karakter pribadi kreatif. Melalui wawancara dengan berbagai informan kunci dapat diketahui bahwa Udjo memiliki pribadi yang sederhana, ulet, disiplin, jujur dan optimis. Karakter ini lahir dari pengalaman hidupnya sejak masa anak-anak, pergaulan dengan masyarakat, dalam lingkungan pendidikan dan lain sebagainya. Aktualisasi diri yang Udjo lakukan tidak lepas dari pengalaman hidupnya, misalnya ia menambahkan sendiri kata Ngalagena, sehingga menjaid Udjo Ngalagena. Ngalagena mengandung makna penuh harapan, mandiri, bebas. Kreativitas Udjo lahir bukan hanya karena potensi yang dimilikinya, tetapi tumbuh dan berkembang melalui interaksi dengan masyarakat dan lingkungannya (pendorong kreatif). Kontribusi terbesar yang membuat Udjo kreatif dan mampu mengembangkan kreativitasnya adalah dorongan dari gurunya, Daeng Soetigna. Perpaduan kekuatan pribadi kreatif, dorongan kreatif, proses kreatif menjadikan Udjo tumbuh menjadi manusia 
kreatif dan mengungkapkan berbagai ekspresinya. Tidak hanya itu, Udjo juga konsisten dengan apa yang dilakukannya. Konsisten membuat pertunjukkan disaat orang menganggapnya aneh, konsisten membuat angklung meskipun berdarah-darah dan mengalami kesulitan mencari bambu, konsisten mengajar anak-anak meskipun sampai larut malam dan tidak mengenal waktu demi tercapainya keinginan dan citacitanya.

Konsistensi ini penting, sebagaimana teori Roger tentang aktualisasi diri yang menekankan pada konsistensi diri dan kongruensi antara diri dan pengalaman (Pervin, 2010). Guna menjaga konsistensi diri dan kongruensi (membuat sama atau selaras), individu mengembangkan sistem nilai yang dipakai untuk mengevaluasi diri dan menjaga sistem diri. Individu berperilaku dalam cara yang konsisten dengan konsep diri mereka walaupun perilaku ini tidak memberikan imbalan pada mereka (Pervin, 2010). Aktualisasi diri Udjo sebagai seorang pendidik dan seniman diwujudkan dengan membuat SAU. Udjo secara konsisten membangun institusinya melalui aktivitas produksi angklung, pendidikan angklung untuk anak dan pertunjukkan, meskipun belum memberikan hasil yang memuaskan, ia terus bekerja dengan tekad suatu saat angklung akan mendunia. Konsistensi dan optimisme akhirnya memberikan hasil dan dampaknya dirasakan bukan hanya oleh diri dan keluarganya tetapi oleh masyarakat lokal hingga mancanegara. Pada saat yang sama kongruensi antara diri dan pengalaman juga terjadi dalam diri Udjo. Diakui oleh semua informan, Udjo benar-benar sosok yang perkataan dan perbuatannya sama. Ciri pribadi ulet, disiplin, jujur dan optimis melekat dalam kepribadiannya sampai akhir hayat. Contoh dari kongruensi Udjo adalah ketika Udjo memandang dirinya sebagai sosok guru yang sayang dengan anak-anak, maka Udjo menerapkan metode belajar yang disenangi anak-anak sehingga anak-anak menikmati dan cepat belajar, misalnya mengajar sambil bermain, menggunakan hand sign sebagai dirigen, bukan hanya itu, dia juga empati dan dekat dengan murid-muridnya dan sering memberikan apresiasi. Contoh lain misalnya, Udjo sering menasehati murid, pengrajin dan karyawannya, dengan mengatakan bahwa pekerjaan yang telah kamu pilih ini kerjakan dengan baik dan cintailah, karena tanpa cinta kamu akan mati sebelum kematian yang sesungguhnya. Katakata yang disampaikan tersebut merupakan saripati dari pengalaman hidupnya dalam menggeluti angklung yang terus dipegang hingga wafat. Udjo sungguh-sungguh bekerja dan mencintai apa yang dikerjakannya dengan berbagai resiko yang dihadapi. Konsistensi dan kongruensi ini membuat kreativitasnya berkembang dan bertahan dan mampu menggerakan oranglain untuk kreatif juga.

Pendekatan 4P dapat dibuat tabulasinya mengacu pada konsep yang dikembangkan oleh Utami Munandar (1988; 2012) dan mengkaitkannya dengan beberapa aspek yaitu aspek siapa (who), apa (what), dimana (where), kapan (when), mengapa (why) dan bagaimana (how). 


\section{Tabel 1}

\section{Strategi 4 P Dalam Menganalisa Kreativitas Udjo Ngalagena}

\begin{tabular}{|c|c|c|c|c|c|c|}
\hline & Siapa & Apa & Bagaimana & Mengapa & Kapan & Dimana \\
\hline Person & Udjo Ngalagena & $\begin{array}{l}\text { Pribadi kreatif } \\
\text { dengan ciri : } \\
\text { 1. Sederhana } \\
\text { 2. Ulet/tekun } \\
\text { 3. Disiplin } \\
\text { 4. Jujur } \\
\text { 5. Optimis } \\
\text { 6. Teguh } \\
\text { Pendirian } \\
\text { 7.Pembelajar } \\
\text { 8. Terbuka } \\
\text { 9. Murah hati } \\
\text { 10. Humoris }\end{array}$ & $\begin{array}{l}\text { Sejak kecil potensi dan } \\
\text { kemampuan Udjo dibidang seni } \\
\text { sudah terlihat dan berkembang } \\
\text { seiring perkembangan } \\
\text { interaksinya. Kepribadian kreatif } \\
\text { Udjo terbentuk diantaranya } \\
\text { karena interaksinya dilingkungan } \\
\text { keluarga, lingkungan } \\
\text { masyarakat, alam, lingkungan } \\
\text { sekolah, lingkungan pendidikan } \\
\text { dan pergaulan dalam komunitas } \\
\text { kesenian Sunda. }\end{array}$ & $\begin{array}{l}\text { Adanya dorongan kuat } \\
\text { dari pribadi Udjo yang } \\
\text { didukung oleh } \\
\text { lingkungan sehingga } \\
\text { membuat bakat dan } \\
\text { kreativitasnya } \\
\text { berkembang terus. }\end{array}$ & $\begin{array}{l}\text { Sejak lahir } \\
\text { hingga } \\
\text { membuat SAU } \\
\text { tahun 1966, dan } \\
\text { selanjutnya } \\
\text { mengem- } \\
\text { bangkan pribadi } \\
\text { dan keluarga } \\
\text { serta } \\
\text { masyarakat }\end{array}$ & $\begin{array}{l}\text { Cicalung } \\
\text { Padasuka }\end{array}$ \\
\hline \multirow[t]{3}{*}{ Press } & $\begin{array}{l}\text { Keluarga : Orang } \\
\text { Tua }\end{array}$ & $\begin{array}{l}\text { Agen sosialisasi } \\
\text { primer : pendidikan } \\
\text { pertama }\end{array}$ & $\begin{array}{l}\text { Menekankan pentingnya jadi } \\
\text { orang pandai, punya ilmu, taat } \\
\text { aturan, punya tata krama }\end{array}$ & $\begin{array}{lcr}\text { Biar hidupnya enak, } & \text { en } \\
\text { lebih } & \text { baik } & \text { dari } \\
\text { kehidupan orang tuanya }\end{array}$ & $\begin{array}{lr}\text { Sejak } & \text { kecil } \\
\text { hingga menikah }\end{array}$ & Cicalung \\
\hline & $\begin{array}{l}\text { Masyarakat dan } \\
\text { lingkungan: teman } \\
\text { sebaya, alam }\end{array}$ & $\begin{array}{l}\text { Agen sosialisasi } \\
\text { sekunder: } \\
\text { Pendidikan kedua }\end{array}$ & $\begin{array}{l}\text { Penekanan pada harmoni dengan } \\
\text { alam dan budaya dalam nilai } \\
\text { silih asah silih asih silih asuh. }\end{array}$ & $\begin{array}{l}\text { Interaksi sosial } \\
\text { membutuhkan } \\
\text { keharmonian, bukan } \\
\text { hanya dengan sesama, } \\
\text { tetapi juga dengan alam } \\
\& \text { budaya. }\end{array}$ & $\begin{array}{l}\text { Saat baru lahir } \\
\text { hingga } \\
1966\end{array}$ & $\begin{array}{l}\text { Cicalung dan } \\
\text { Padasuka }\end{array}$ \\
\hline & $\begin{array}{l}\text { Sekolah : Guru, } \\
\text { mentor }\end{array}$ & $\begin{array}{l}\text { Agen sosialisasi } \\
\text { sekunder: namun } \\
\text { sangat berpengaruh } \\
\text { khususnya Sosok } \\
\text { Daeng Soetigna }\end{array}$ & $\begin{array}{l}\text { Penekanan pada ilmu seni musik } \\
\text { dan ekspresi seni } \\
\text { Gurunya mendorong Udjo } \\
\text { membuat SAU }\end{array}$ & $\begin{array}{lr}\text { Sekolah memberikan } \\
\text { ilmu sebagai bekal } \\
\text { individu ralam } \\
\text { perubahan dan ekspresi } \\
\text { kreativitas. }\end{array}$ & $1937-1970$ & $\begin{array}{l}\text { HIS, SGB, } \\
\text { SGCB dan } \\
\text { belajar } \\
\text { angklung } \\
\text { dari Daeng } \\
\text { Soetigna }\end{array}$ \\
\hline Process & $\begin{array}{l}\text { Udjo Ingin } \\
\text { berkontribusi } \\
\text { dalam } \\
\text { pengembangan } \\
\text { seni tradisi }\end{array}$ & $\begin{array}{l}\text { Udjo memilih fokus } \\
\text { pada seni tradisi } \\
\text { karena rasa } \\
\text { cintanya pada seni } \\
\text { Sunda dan dunia } \\
\text { pendidikan } \\
\text { sehingga ia } \\
\text { memiliki ilmu } \\
\text { untuk } \\
\text { mengembangkan } \\
\text { seni tradisi dan } \\
\text { berekpresi melalui } \\
\text { seni khususnya } \\
\text { calung, angklung } \\
\text { dan karawitan } \\
\text { sunda. }\end{array}$ & $\begin{array}{l}\text { Melalui } 4 \text { tahapan: } \\
\text { 1.Persiapan: Udjo belajar seriua } \\
\text { tentang Angklung dari Daeng } \\
\text { Soetigna. } \\
\text { 2. Inkubasi: Refleksi dan } \\
\text { merenung "Jika Daeng } \\
\text { Soetigna bisa menciptakan } \\
\text { angklung diatonik maka Udjo } \\
\text { bisa apa?" } \\
\text { 3.Iluminasi: } \\
\text { Muncul gagasan "aha": Ingin } \\
\text { menciptakan Saung Angklung } \\
\text { sebagai tempat pendidikan } \\
\text { angklung sebagai jawaban atas } \\
\text { pertanyaan kritisnya. } \\
\text { 4. Verifikasi: } \\
\text { Membuat dan } \\
\text { mengembangkan angklung } \\
\text { sunda, membuat kreasi } \\
\text { pertunjukkan, menjadikan } \\
\text { angklung memiliki fungsi } \\
\text { hiburan dan pendidikan. }\end{array}$ & $\begin{array}{l}\text { Untuk memastikan } \\
\text { bahwa karya/ kreativitas } \\
\text { yang dibuat oleh Udjo } \\
\text { benar-benar sesuai } \\
\text { dengan visi dan } \\
\text { keinginannya serta } \\
\text { didukung oleh orang- } \\
\text { orang terdekat, guru dan } \\
\text { masyarakatnya. }\end{array}$ & $\begin{array}{l}1958- \\
1966\end{array}$ & Padasuka \\
\hline Product & $\begin{array}{l}\text { Udjo mewujudkan } \\
\text { Kreativitasnya } \\
\text { dengan } \\
\text { menciptakan SAU }\end{array}$ & $\begin{array}{l}\text { Saung/sanggar } \\
\text { pengembangan seni } \\
\text { tradisi angklung } \\
\text { dan seni tradisi } \\
\text { lainnya sebagai } \\
\text { media pendidikan } \\
\text { dan pertunjukkan } \\
\text { seni yang } \\
\text { memadukan } \\
\text { harmoni alam dan } \\
\text { budaya. }\end{array}$ & $\begin{array}{l}\text { Pribadi kreatif Udjo, press } \\
\text { (pendorong/tekanan) baik dari } \\
\text { lingkungan keluarga, masyarakat } \\
\text { dan sekolah serta adanya proses } \\
\text { kreatif yang dijalani pada } \\
\text { akhirnya membuat Udjo mampu } \\
\text { menciptakan kreativitas berupa } \\
\text { pengembangan seni tradisi } \\
\text { angklung dan seni tradisi lainnya } \\
\text { sebagai media pendidikan dan } \\
\text { pertunjukkan seni. Berbagai } \\
\text { kreasi Udjo disatukan dalam } \\
\text { wadah SAU. } \\
\text { Selanjutnya setelah SAU berdiri, } \\
\text { ia mengembangkan kreativitas } \\
\text { dan mengajak masyarakat untuk } \\
\text { terlibat bersama-sama. }\end{array}$ & $\begin{array}{l}\text { Seni tradisi angklung } \\
\text { masih sebatas berfungsi } \\
\text { sebagai hiburan padahal } \\
\text { dapat dikembangkan } \\
\text { lebih lanjut untuk } \\
\text { pendidikan,pelatihan, } \\
\text { pengembangan bakat } \\
\text { anak. Dalam dimensi } \\
\text { yang lebih luas, ikut } \\
\text { serta membina dan } \\
\text { melestarikan budaya } \\
\text { sunda. } \\
\text { Kreativitas Udjo lahir } \\
\text { dari masyarakat } \\
\text { sehingga harus tumbuh } \\
\text { dan berkembang } \\
\text { bersama masyarakat. }\end{array}$ & $1966-2001$ & Padasuka \\
\hline
\end{tabular}

Sumber : Utami munandar dan berbagai sumber, diolah oleh penulis 2015 
Selanjutnya dikaitkan dengan peranan lingkungan, seperti lingkungan keluarga, lingkungan sekolah dan masyarakat.

Udjo berhasil menjadi pribadi kreatif karena berbagai faktor seperti pendidikan orang tua, dorongan dari masyarakat dan lingkungan sekolah. Pribadi kreatif dan dorongan eksternal khususnya dorongan dari gurunya, Daeng Soetigna membuat Udjo mampu berkembang dalam berbagai situasi dan kondisi zaman. Peran gurunya, Daeng Soetigna yang sangat besar dalam menginspirasi dan mengembangkan kreativitas Udjo dibidang seni tradisi sehingga melahirkan SAU. Daeng Soetigna bukan sebatas guru, lebih dari itu, ia menjadi motivator, sahabat dan guru dalam kehidupan Udjo. sebagai murid yang kemudian menjadi seniman dan pemain angklung yang pada akhirnya dapat menjadi pelatih. Udjo berhasil menggerakan ratusan masyarakat sehingga berprofesi sebagai pembuat angklung dari yang sebelumnya tidak ada satupun orang di Padasuka yang membuat angklung. Udjo berhasil menggerakan sektor ekonomi melalui seni tradisi yang dalam konteks saat ini adalah ekonomi kreatif. Melalui invensi tradisi yang dilakukan Udjo di SAU, angklung mendunia dan melalui perjuangan SAU bersama pemerintah dan komunitas angklung lainnya akhirnya disyahkan oleh UNESCO menjadi warisan dunia tak benda pada tahun 2010.

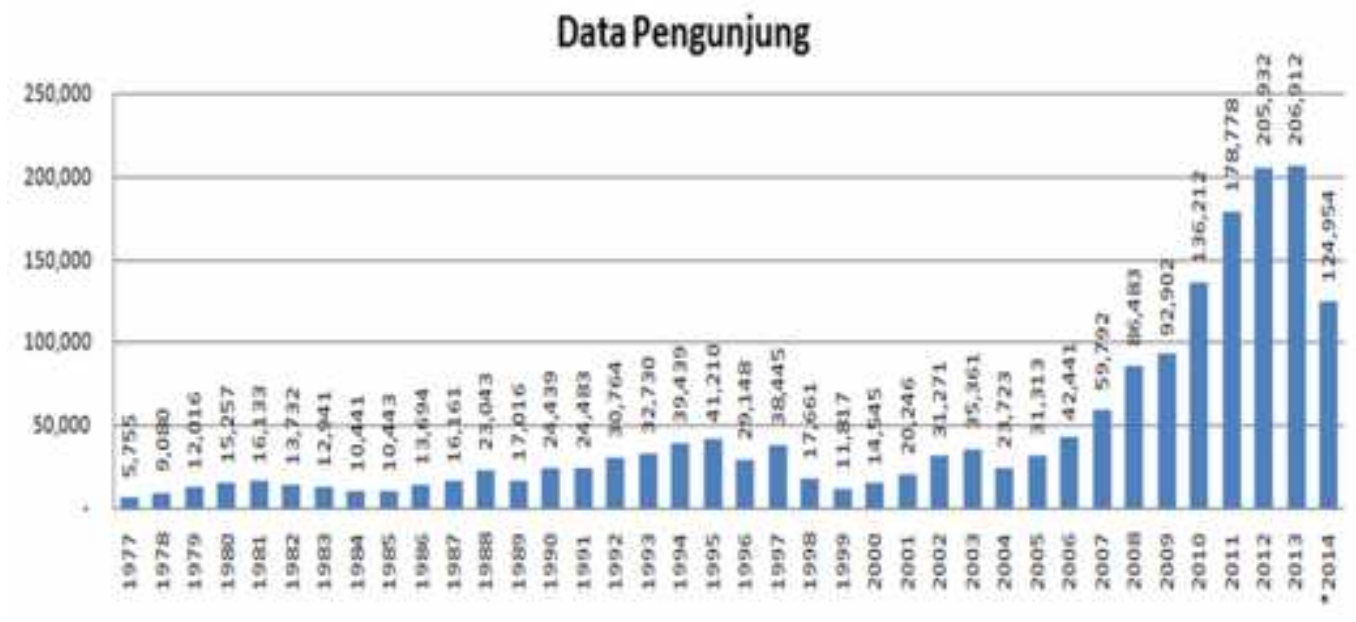

Grafik 1. Data Pengunjung Tahun 1977-2014

(Sumber: Hrd SAU, ket. data 2014 hingga Juni)

Sebagai pribadi yang kreatif, Udjo bukan hanya berhasil menginspirasi, mendidik dan menghibur orang lain, lebih dari itu, Udjo berhasil menggerakan masyarakat. Ribuan orang berhasil digerakkan oleh Udjo, baik
Udjo telah berhasil menjadi role model bagi masyarakat di sekitarnya dan masyarakat luas lainnya. Saung Angklung Udjo merupakan produk kreatif Udjo yang didalamnya ada berbagai seni tradisi dan kebudayaan Sunda 
yang dipraktekkan, diajarkan dan dilestarikan melalui suatu aktivitas rutin yang berlangsung terus-menerus sehingga menjadi suatu tradisi baru. Di SAU, berbagai seni tradisi Sunda diciptakan, diproduksi, dikemas dan dilestarikan melalui berbagai atribut, simbol-simbol dan dikreasikan dalam berbagai bentuk seperti pertunjukkan, produksi alat musik angklung, pelatihan, pendidikan dan lain sebagainya yang dikaitkan dengan atraksi pariwisata. SAU yang pada awalnya didirikan dengan spirit kecintaan Udjo Ngalagena terhadap seni tradisi Sunda khususnya pendidikan dan pelestarian angklung kemudian berkembang menjadi objek tujuan wisata budaya yang mendunia. SAU telah menjadi contoh keberhasilan dari pembangunan seni tradisi yang berkembang menjadi pembangunan wisata budaya yang berbasis pada kreativitas.

\section{Regenerasi Kreativitas Udjo Ngalagena}

Langkah awal yang dilakukan oleh Udjo dalam mengelola kreativitasnya adalah menciptakan penerus-penerus kreativitas (subyek kreatif) untuk mengelola produk kreatifnya (obyek kreatif). Pengelolaan kreativitas pada skala kecil, yakni skala keluarga, khususnya istri dan anak-anaknya menjadi prioritas yang dilakukan oleh Udjo. Permasalahan regenerasi seni tradisi merupakan persoalan yang sudah diantisipasi oleh Udjo Ngalagena sehingga ia memaksa semua anak-anaknya untuk belajar angklung. Suka tidak suka, mau tidak mau anaknya harus belajar dan menurut perintah Udjo. Semua anaknya mengalami hal yang sama, dimarahi, dipaksa dan lain sebagainya, bahkan belajar angklung tidak mengenal waktu hingga larut malam. Konteks jaman saat itu orang tua yang otoriter adalah hal yang wajar dan lumrah. Hampir semua gaya mendidik anak adalah otoriter karena jamannya masih feodal. Masa-masa itu adalah masa yang membuat anak-anaknya tertekan. Puluhan tahun berikutnya ketika anak-anak sudah mulai remaja dan dewasa baru mulai ada dialog. Udjo mulai mengubah sikap dan cara mendidik anak. Mulai ada dialog antara anak dan orang tua, mulai ada apresiasi yang lebih buat anak meskipun sikap disiplin dan tegas masih melekat pada diri Udjo. Baru ketika cucu sudah mulai banyak, jamanpun berubah, pola yang diterapkan Udjo jauh lebih demokratis, dimana anak diberikan kebebasan untuk berekpresi dan mengembangkan kreativitasnya masing-masing.

Udjo menerapkan prinsip dan filosofi Sunda dalam proses regenerasi. Salah satu filosofi yang diterapkan fisolofi silih asah (saling mengasah atau mengajari), silih asih (saling mengasihi) dan silih asuh (saling mengasuh). Fase regenerasi ini merupakan model yang dilakukan oleh Udjo berdasarkan kondisi dan latar belakang Udjo, yang kemudian secara perlahan dilakukan perbaikan terus menerus dalam rangka merespon perubahan jaman dan merespok perkembangan anak-anaknya. Jika metode pewarisan yang dilakukan secara otoriter melahirkan keterpaksaan dan perlawanan, metode pewarisan melalui dialog melahirkan rasa "dihargai keberadaannya dan dianggap" sehingga dapat memberikan kontribusi dan 
kreativitas lebih maka metode demokratis melahirkan apresiasi dan kebahagiaan bagi anak-anaknya tetapi dibalik itu ada tanggungjawab yang berat. Filosofi ini menjelaskan bahwa hubungan antara manusia dengan sesama manusia dalam masyarakat Sunda yang harus saling mengasah atau mengajari, saling mengasihi, dan saling mengasuh menciptakan suasana kehidupan masyarakat yang diwarnai keakraban, kerukunan, kedamaian, ketentraman, dan kekeluargaan.

Selain melakukan proses regenerasi kepada keluarga, Udjo juga melakukan sharing kreativitas kepada masyarakat dengan menjadikan seni tradisi Sunda dan berbagai potensi lainnya sebagai sumber daya kreatif sehingga diterima dan didukung masyarakat. Udjo Ngalagena berhasil melakukan pengelolaan kreativitas dengan melibatkan partisipasi masyarakat yang bersinergi dengan sektor pariwisata sehingga produk SAU memberikan nilai tambah secara ekonomi, sosial dan budaya yang mampu menggerakan masyarakat untuk berkreasi. Hal ini penting karena jika sekedar transformasi budaya tanpa komponen dan nilai tambah secara ekonomi maka sangat berat untuk mendorong pergerakan masyarakat.

\section{PENUTUP}

\section{Simpulan}

Secara singkat, temuan lapangan yang menguatkan dan menjawab pertanyaan utama penelitian tentang bagaimana Udjo Ngalagena menjadi pribadi kreatif yang produk kreatifnya dapat bertahan selama lebih dari 50 tahun dapat dijelaskan bahwa Udjo berhasil menjadi pribadi kreatif karena berbagai faktor seperti pendidikan orang tua, dorongan dari masyarakat dan lingkungan sekolah dan dorongan dan karakter pribadinya sendiri yaitu ulet, disiplin, jujur dan optimis. Udjo sebagai kekuatan utama SAU berhasil menciptakan productive output berupa pelatihan/pendidikan, pertunjukkan, produksi alat musik angklung dan berbagai bentuk lainnya berdasarkan pada akan budaya dan tradisi Sunda. Kenyataan bahwa kreasi yang mengacu pada nilai tradisi akan lebih mudah diterima oleh masyarakat sehingga dapat menjadi suatu tradisi baru serta adanya nilai tambah secara sosial, budaya dan ekonomi merupakan temuan lapangan yang menguatkan bahwa bertahannya SAU dan berbagai kreativitas di dalamnya selama 50 tahun terjadi karena faktor-faktor tersebut.

Implikasi teoritis dari kajian ini dapat dijelaskan bahwa kreativitas yang secara umum dikaji dari aspek 4P dapat diperluas dengan memasukkan aspek keberlangsungan dan keberlanjutan kreativitas melalui penciptaan tradisi baru dan penciptaan sistem kreatif.

Kreativitas yang mengacu pada unsur budaya akan bertahan lama jika produk kreatif yang dihasilkan dapat menjadi suatu tradisi baru. Namun, bila tradisi baru yang diciptakan luntur maka produk kreatif tersebut juga akan luntur. Supaya produk kreatif tetap langgeng maka tokoh yang menciptakan produk tersebut harus terus kreatif menciptakan tradisi baru dan membuat sistem 
pengelolaan kreativitas sehingga produknya

tetap bertahan.

\section{DAFTAR PUSTAKA}

\section{Buku}

Bachtiar, Harsya. 1983. Kreativitas, Suatu Tinjauan dari Sosiologi, dalam Sutan Takdir Alisyahbana (ed.), Kreativitas. Jakarta: Penerbit Dian Rakyat.

Ember, Carlol R dan Melvin Ember. 1996. Anthropology. New Jersey: Prentice Hall, Upper Saddle River

Fontana, Avanti. 2009. Innovate We Can! Manajemen inovasi dan Penciptaan Nilai.Jakarta: PT. Gramedia Widiasarana Indonesia.

Ife, Jim. 2013. Community Development In An Uncertain World. New York. USA.Cambridge University Press.

Neuman, W. Lawrence, 2013. Social Research Method: Qualitative and Quantitative Approaches. Boston: Allyn \& Bacon

Munandar, Utami. 1988. Kreativitas Sepanjang Masa. Jakarta : Pustaka Sinar Harapan 1990. Mengembangkan Bakat dan Kreativitas Anak Sekolah-Petunjuk Bagi Guru dan

Orang Tua, Jakarta: Gramedia 2009. Kreativitas \& Keberbakatan. Jakarta: Gramedia Pustaka Utama 2004. Pengembangan Emosi dan Kreativitas. Jakarta : Rineka Cipta 2012. Pengembangan Kreativitas Anak Berbakat. Jakarta : Rineka Cipta

Pervin, Lawrence A. dan Daniel Cervone, Oliver P. John. 2010. Psikologi Kepribadian Teori dan Penelitian. Edisi Kesembilan. Jakarta: Kencana

Semiawan, R. Conny. 2009. Kreativitas Keberbakatan: Mengapa, Apa dan Bagaimana. Jakarta; PT.Index.

Soemardjan, Selo. 1983. Kreativitas, Suatu Tinjauan dari Sosiologi, dalam Sutan Takdir Alisyahbana (ed.), Kreativitas. Jakarta: Penerbit Dian Rakyat.

Syafii, Sulhan. 2009. Udjo Diplomasi Angklung. Jakarta: PT Grasindo

Sztompka, Piötr. 2004. Sosiologi Perubahan Sosial. Jakarta: Prenada Media.

\section{Jurnal}

Almasitoh, Ummu Hany, Kepribadian Individu Kreatif: Afiliatif \& Asertif. Magistra No. 83 Th. XXV Maret 2013, Universitas Widya Dharma, Klaten ISSN 02 15-9511

Asharinne, Loulasela, 2012. Identifikasi Proses Pengembangan Inovasi Dalam Pariwisata Budaya (Studi Kasus: Saung Angklung Udjo, Kota Bandung). Jurnal Perencanaan Wilayah dan Kota A SAPPK, ITB 
Azali, Kathleen. Ludruk: Masihkah Ritus Modernisasi? Jurnal Lakon Vol. 1 No. 1 Mei 2012 UNAIR.

Surabaya

Canavan, Claire. Created by the Ensemble: Generative Creativity and Collective Creation at the Dell'Arte International School of Physical Theatre. Theatre Topics 22.1 (Mar 2012): 49-61. Johns Hopkins University Press, United States

Eger, John M. Building Creative Communities: The Role of Art and Culture. The Futurist Journal (Mar/Apr 2006): 18-22.

Fischer, G. .2014. "Learning, Social Creativity, and Cultures of Participation" in A. Sannino, \& V.

Ellis (Eds.), Learning and Collective Creativity: Activity-Theoretical and Sociocultural Studies, Taylor \& Francis/Routledge, New York, NY, pp. 198-215. http://13d.cs.colorado.edu/ gerhard/papers/2013/helsinki.pdf.

Fischer, Gerhard and Frank Shipman (2011), Collaborative Design Rationale And Social Creativity In Cultures Of Participation, Volume 7 (2), August 2011, An Interdisciplinary Journal on Humans in ICT Environments . ISSN: 1795-6889, University of Colorado, USA

Glăveanu, Vlad Petre. Creativity and folk art: A study of creative action in traditional craft. Psychology of Aesthetics, Creativity, and the Arts. American Psychological Association. 2013, Vol. 7, No. 2, $140-154$

Hassan, Sri Martina Intan Permatasari. 2013, Saung Angklung Udjo Sebuah Model Transformasi Nilai Budaya Melalui Pembinaan Seni Untuk Membangun Ketahanan Budaya. Tourism and Hospitality Essentials Anthology (THE Anthology), Edisi I, Desember 2013 Hal 5-17

Milyartini, Rita A \& Chaedar Alwasilah. Saung Angklung Udjo Sebuah Model transformasi Nilai Budaya Melalui Pembinaan Seni Untuk Membangun Ketahanan Budaya. FPBS Universitas Pendidikan Indonesia, Jurnal Integritas, Vol. 1 No. 1, Desember 2012

Moersid, Ananda Feria. Re-Invensi Batik Dan Identitas Indonesia Dalam Arena Pasar Global. Fakultas Seni Rupa - Institut Kesenian Jakarta, 2013

Mushnikova, E, Creativity Of Altai Artist, G.F. Borunov. Himalayan and Central Asian Studies 18.3/4 (Jul-Dec 2014): 169-180, Himalayan research and Cultural Foundation, New Delhi, India

Palaniappan, Ananda Kumar. Culture-based Creativity: Concept and Applications. University of Malaya, Malaysia. Creativity and Leisure: An Intercultural and Cross-disciplinary Journal Vol. 1, No. 2 (2012) 195-204. Research Publishing Services

Supariadi \& Warto. 2012. Regenerasi Seniman Reog Ponorogo Untuk Mendukung Revitalisasi Seni Pertunjukan Tradisional Dan Menunjang Pembangunan Industri Kreatif. Pusat Penelitian Dan Pengembangan Pariwisata dan Budaya (Puspari) Lembaga Penelitian Dan Pengabdian Kepada Masyarakat Universitas Sebelas Maret. Surakarta. 